\title{
Security And The Challenges Of Securing Nigerian State
}

\author{
Ejiroghene Augustine Oghuvbu ${ }^{a}$ \\ ${ }^{a}$ Department of History and International Studies \\ Faculty of Arts, Delta State University, Abraka, Nigeria \\ ORCID: https://orcid.org/0000-0003-1422-3806 \\ Email: augustine4best@yahoo.com
}

Article History: Received: 10 November 2020; Revised 12 January 2021 Accepted: 27 January 2021; Published online: 5 April 2021

\begin{abstract}
Nigeria, like most developing States is still grappling with the task of nation - building, responsive democratic order and a just and secured polity. The task over the years has remained arduous and seemingly illusive. Presently, the menance of Boko Haram, the marauding herdsmen militancy, the new face of militancy in the Niger Delta, the spate of kidnappings, armed robberies, and ethno-regional intolerance, the vociferous separatist agitations in the South-East and South-South and the deteriorating living conditions have continued to create survival, stability and security challenges and threaten the very existence of Nigeria as a federation. Against this backdrop, this paper therefore attempts to identify some of the emerging trends of security challenges in Nigeria with a view to diagnosing their causes and examining their implications on the corporate existence of Nigeria. This paper adopted the analytical method and relied on the natural theory of state to posit that the solution to the disturbing trend of security challenges in Nigeria is employment generation and genuine implementation of poverty alleviation programmes in the polity
\end{abstract}

Keywords: National Security, Insecurity, Security Challenges, Nigerian State, Unemployment, Poverty.

\section{Introduction}

Nigerian State is grappling with continuous rising incidences of insecurity, repeated pattern of attacks on innocent citizens and vociferous separatist agitations from ethnic cleavages. The incidences of insecurity are a reflection of the series of antithesis that characterized the Nigerian State from her Colonial past. Religious and ethnic differences, socio-economic and political settings, differential legal system coupled with ethnicity which are embedded in the struggle for political and natural resources control which are exhibited by the political leaders. This is further intensified by elements of globalization, climate change, natural disasters, hnhand proliferation of small arms and light weapons of mass destruction, executive lawlessness, corruption, and weak security system, lack of institutional capacity, porous borders and leadership ineptitude. These have contributed to create impetus for the general insecurity in the country leading to scores of deaths if innocent citizens, foreigners, some members of the State's security personnel, elected officials and many civil servants across the country (Eke, 2013; Ndubuisi, 2017).The insecurity challenges in Nigeria has assumed formidable dimensions forcing the country's political and economic managers and, indeed the entire Nation, to rue the loss of their loved ones, investments and absence of safety in most parts of the country. The number of violent crimes such as kidnappings, ritual killings, carjackings, suicide bombings, religious killings, politically-motivated killing and violence, ethnic clashes, armed banditry and other forms of violent crimes has increasingly become the regular signature that characterizes life in Nigeria since 2009' (Imhonopi \& Urim 2012 cited in Onifade, Imhonopi \& Urim, 2013:53). In spite of the government responses to stem the tide of insecurity in the societythrough planned strategic, institutional, comprehensively mutual and integrative approaches, the challenges of insecurity remained persistent, intense and impervious. Not only has the continued State of insecurity threatened the very existence of Nigeria as a federation and created the ecology of fear, disquiet and anxiety, it has also meted a deadly blow or what Imhonopi and Urim, 2012 cited in Onifade et al. (2013) called 'spectral bite' to industrial development. The destruction of the needed infrastructure has taken the country many years backwards.

Security challenges in Nigeria is a product of failure of political leadership due to bad leadership, poor governance, militarization of the society and State violence leading to acute youth unemployment, economic crisis of development, abject poverty, poor health prospects and widespread malnourishment, heightened crime rate and other forms of poor human development indices in Nigeria. According to Otite, 1999 cited in Omemma (2017), security challenges and communal violence in the country are product of prevalence of dominance and subordination which are characteristic of an encapsulating society with competing interest. This, for instance, is largely responsible for the incessant attacks on agrarian communities by nomadic herdsmen who move across 
communities in parts of the country to graze livestock on farmlands. This paper therefore argues that insecurity is people's relative feeling of the presence of economic, political, social, cultural and psychological fear. Of these forms of insecurity, economic insecurity is the most common and triggers consciousness of other forms of insecurity into existence. In simple terms, economic insecurity is the absence of jobs, good health prospects, life enhancing opportunities, education and creative policies that cater for short, medium and long term needs of the different cadre of the population. Thus, this paper attempt to identify some of the emerging trends of security challenges in Nigeria with a view to diagnosing their causes and examining their implications on the corporate existence of Nigeria.

\section{Review Of Related Literature}

\subsection{The Concept of Security and Insecurity}

Various scholars across the globe have postulated different view point on the concept of security and insecurity the term ' Security' originates from Latin word 'Se-curus'. 'Se' means 'without' and 'Curus' means 'uneasiness'. This implies that security originally meant libration from uneasiness or peaceful situation without any risks or threats. Thus, security has a wider meaning such as 'to feel safe', 'to be protected' and it is used to describe a situation without any risks or worries (UNDP, 2002 Cited in Peterside, 2018). Security is broadly viewed as "'Freedom from danger or threats to an individual or a nation. It is the ability to protect and defend oneself, be it an individual or a nation, its cherished values and legitimate interests and the enhancement of well-being' (Mijah, 2007 cited Eugina 2013;60). Nwagboso (2012) cited in Adagbabiri and Okolie (2018: 48) argues that security is "'commonly associated with the alleviation of threat to the survival of individuals or groups". Thus, for insecurity can be equated with freedom from present and future danger, harm or anxiety.

In the view of Onoja (2014: 35), security is 'peoples' relative feeling of being secure from economic, political, socio-cultural and psychological fear.' This implies that security must be people driven or oriented to assure citizens that government is competent, capable and efficiently ready to guarantee their safty and freedom of movement, association that enables them to carry out their socio-economic activities without molestation, intimidation, harassment or violent threat from any person or group within and outside of the polity (Eke, 2013). Security is often equated with national security because the contextual meaning of both applies to human security. According to Peterside (2018:854), National life that may arise as a result of human actions or inactions, or from disaster such as flood, earthquake, famine, drought, disease and other natural calamitous events resulting in deaths, humansuffering and material damage.' In the context of this paper, security entails protecting the citizens from chronic threat such as poverty, hunger, unemployment, diseases and natural diseases. Thus, noted by United Nations Development Proggramme (2002) stems from three fundamental convictions:

(i)The sanctity and inviolability of human life,

(ii)The universality and dignity of human life and

(iii)The existential imperatives of the value for individual safety in a world full of multifarious threats.

Therefore, Security is rooted in three basic instincts of self -preservation, self-extension and self-fulfillment (UNDP, 2002). On the other hand, insecurity is the opposite of security. It is ' a state of being subjected to danger or threat. However, because of the very many ways in which insecurity has been described in association with the various ways in which it affects individuals, some of the common descriptors of insecurity include wants to safety, danger, hazard,uncertainty, want to confidence, doubtful, inadequately guarded or protected, lacking stability, troubled, lack protection and unsafe, to mention few' (Adagbabiri \& Okolie, 2018 : 49). Insecurity according to Beland (2005), is the state of fear or anxiety stemming from a concrete or alleged lack of protection. It refers to lack or inadequate freedom from danger. This definition reflects physical insecurity which is the most visible form of insecurity such as economic and social insecurity.

\subsection{Insecurity in Nigeria: An Overview}

Insecurity is the antithesis of security it is a situation where human and national security of a State is compromised by internal or externalforces or interests exacerbated by the former's weak or poor economic, military and /or human resource development conditions" (Onifade et al., 2013 : 54). Since 1960, different administrations and regimes have always reiterated the essentials of security as the core goal and primary purpose of government. In fact every successive government in Nigeria since 1960 till date always integrated the subject matter of national security in their vision and mission statements. Section 14(2) (b) of 1999 constitution, upon which the Nigeria's fourth Republic operates, stipulated that the security and welfare of the people shall be primary purpose of government. The implication is that government has the onerous duty to providing safe haven for her citizenry, aside from securing the territorial integrity of her borders from external aggression (Eke, 2013 : Oka, Ufomba \& Benjamin, 2018).

The public security agencies and institution saddled with the task of providing security in Nigeria include the Police personnel, the Army, the Navy and the Air Force respectively. Other prominent institutions include the 
National Intelligence Agency (NIA), Nigeria security and Civil Defense Corps (NSCDC),Nigeria prisons Service (NPS), Departments of State Service (DSS), Federal Roads Safety Corps (FRSC), Nigeria Customs Service (NCS), Nigeria Immigration Service (NIS), Federal Fire Service and National Emergency Management Agency (NEMA), Defence Intelligence Agency (DIA), among others. Also, there are at the state levels, community policing (vigilante groups) and other voluntary organizations that are involved in security-related matters. However, despite all of these, hardly can the lives and property of the generality of the ordinary citizens be said to be secured. Since 1999 to date, Nigerian State has encountered multidimensional security threats, which include communal clashes, farmers and herdsmen' clashes, armed robberies, kidnappings, politically motivated assassinations, insurgencies, politically motivated suicide bombings and ethno-religious conflicts (Yagboyaju, 2016), human trafficking and nefarious activities of gangsters/cultist (Ndubuisi, 2017).

To, security challenges have assumed a monstrous dimension in the country both in the frequency of occurrence and the sophistication in character, especially since the return to civilian regime in 1999. Hitherto, security challenges in the country were infrequent and restricted to armed robbery and ethno-religious violence, but since the democratization of the Nigerian political landscape with its attendant's rights and freedom of expression and association, the trend of security challenges has attained a bewildering dimension. Therefore, Nigerian State is currently enmeshed in a myriad of security challenges that pose a threat to the consolidation of democratic governance (Omemma, 2017).

According to Aning, 2016 cited in Yagboyaju and Akinola (2019:3), most of these security challenges "have emerged partly as a result of multiple socio-ecnomic injustices, including but not limited to marginalization, social inequality, political exclusion, corruption, economic deprivation, unequal allocation and distribution of state resources." Despite strong optimism that a returned to democratic system of government 1999 would abolish ethnicity and ethno- religious arises, the country continues to be driven by tides of ethnic hostilities with devastating consequences (Kwaja, 2009). Babangida (2002:11) enumerates such consequences as "a waste of enormous human and material resources leading to fragility of the economy and its political process."

However, $\mathrm{n}$ the bid to control the frequency of occurrence of the forms of insecurities listed above, the federal government of Nigeria allotted over \#5 trillion for the defense of the territorial security and internal cohesion among the myrials of ethnic nationalities in the country (Falana, 2015 cited Ndubuisi, 2017). Similarly, Ewetan and Urhie, 2014 cited in Ndubuisi (2017:54) portend that "the wave of insecurities in the country prompted the federal government to make a huge allocation to security in 2013 budget. Also, Omonobi (2016:4) noted that "the 2016 appropriation bill proposed two hundred and ninety four billion, five hundred and twenty five million, seven hundred and ninety five thousand, seven hundred and two naira (N294,525,795,702) as a financial plan for the ministry of Defense, also N57,730,068,052 and N283,091,240,698 was proposed for the National Security Adviser and Police Formations and Command respectively. Federal government in 2016 also made a remarkable effort by increasing the staff strength of the Nigerian Police". In the 2020 revised appropriation bill, the federal government allotted over N10 trillion for the defense of the territorial security. In spite of the government responses to stem the tide of insecurity in the country through planned strategies, institutional, comprehensively mutual and integrative approaches, the challenges of insecurity remained persistent, intense and impervious.

The atrocious acts of insecurity in the country has given rise to serious breakdown of law and order and loss of confidence in the security agencies to provide the necessary leverage for the security of lives and property of citizens, most especially in the wake of the new dimension involving suicide bombers and the allegations that the government and security agencies have been infiltrated by terrorists. The implication of these allegations and the kind of psychological effects it impacted in the minds of Nigerians are better imagined than said particularly following the impunity with which perpetrators of these dastardly acts continue to kill, destroy, disrupt businesses and normal life especially in the Northeast of the country as if there is no government in existence in Nigeria. While the federal government is busy fighting the seen threats to human existence such as terrorism, armed robbery attacks, human trafficking, kidnappings, insurgencies, political assassination, etc, the government ignored the unseen forces such as poverty, hunger, weak economy, diseases, unemployment and underemployment, etc, which cannot be stopped by the best security professional and weapons arsenals. Thus, it can be argued that "approaching the question of security from a political state or militaristic angle is defective. The more fundamental basis for security lies in freedom from poverty, joblessness, disease, arbitrary power and ignorance. Indeed, there can hardly be security amidst starvation and no true freedom built on the foundation of injustice" (Adagbabiri \& Okolie, 2018:49).

\subsection{Causes of Insecurity in Nigeria's Forth Republic}

Insecurity is a result of malignant environment dominated by man's insensitivity to man (Otto \& Ukpere, 2012 cited in Adagbabiri \& Okolie, 2018). Several reasons have been advanced regarding the causes of insecurity. The factors responsible for incidences of insecurity as discussed below are not peculiar to Nigeria alone but may apply to other parts of the world. Ewetan and Urhie (2014:44) grouped the causes of insecurity in Nigeria's forth republic into two major categories which include internal and external causes. However, they focused on the internal causes of insecurity which they identified to include suspicion and distrust among various ethnic groups 
and among the major religions; inability of Nigerian leaders to tackle development challenges, distribution of state resources equitably, over-zealousness and desperation of political gladiators to win elections or remain in office at all cost, political corruption, crises of resource control and revenue sharing; inadequate funding of the police and other security agencies; lack of modern equipments both in weaponry and training; poor welfare of security personnel, inadequate staff of security personnel and porous borders". Onifade et al., (2013:54) allude to absence of institutional capacity resulting in government failure, the gaping chasm of inequality and absence of fairness and justice, ethno-religious conflicts, disconnection between the people and government, weak and Koorly funded military establishment, interagency rivalry, non-prosecution of perpetrators of violence in Nigeria, porous borders, rural-urban drift and social irresponsibility of multinational companies as factors responsible for insecurity in Nigeria. Ujomu (2001:245) identified the causes of insecurity in Nigeria to include "the prolonged period of military dictatorship with the attendant economic decay, corruption, abuse of human rights, depreciation of human dignity and general collapse of social infrastructures".

According to Adagbabiri and Okolie (2018:50-51), the main causes of insecurity in Nigeria's forth republic include but not limited to the structure of the state and Nigeria's federalism, non-separation of state and religion, politics of exclusion, the failure of Nigerian state and its institutions, economic disempowerment, culture of patriarchy and gerontocracy ignorance and poor political consciousness,, corruption and incompetent regimes, poverty and proliferation of small arms, poor welfare of the police, gross party indiscipline and inefficient public utilities and chronic challenge of youth unemployment, population explosion, low level of productivity and per capital income, acute food shortage, widespread ethnic tensions and hatred and monetization of the labour market which have cause lots of unemployed graduates to go through a lot of mental torture in the process of securing jobs". In fact, many of the previous regimes, especially the civilian regimes of Shagari, Obasanjo and Buhari and the military regimes of Abacha and Babangida had myopic, perverted and unviable ideas of national security. The security thrust of these regimes focused on the maintenance of personal security and power to the detriment of the long-term goals of national development. This supports the assertions of Eke (2013:96) that "security is development and without development there can be no security, there would be no development. No meaningful development can take place in the midst of insecurity in a democratic society".

\subsection{Implications of Security Challenges in Nigeria}

Insecurity has serious implications on national integration, socio-economic networking, peace and peace building, atmosphere of unity and general development of Nigerian state. Given the high rate of acute unemployment and poverty profile in the country, it is not strange that Nigeria is plagued by security challenges. The implication is that "the army of unemployed graduates and trained youths in Nigeria is ready asset to enemies of the country who recruit themselves to subvert the country. For instance, most arrowheads of Boko Harram insurgents, the Niger delta Avengers (NDA), Movement for the Emancipation of the Niger Delta (MEND), Movement for the Actualization of the Sovereign State of Biafra (MASSOB), Indigenous Peoples of Biafra (IPOB) and other volatile youth groups swarming across the country are Nigerian graduates of various disciplines without job to justify their endeavour. Others in their midst are trained in technical areas with no money to set up their own trade" (Omemma, 2017:131). Thus, there is no gain saying the fact that the poor and the employed whoa re largely the youths would become a raw material for security threat. The new trend and dynamic of security challenge sin Nigeria is attributed to the prevalence of poverty and acute unemployment in Nigeria.

Invariably, tendencies that inhibit or disrupt socio-economic and political activities across the country automatically qualify for security challenges and contribute to the retardation of democracy in Nigeria. They include but not limited to Boko Haram insurgency, the Niger Delta Militancy, human trafficking, incessant kidnappings, armed robberies, political motivated assassination, the menace of herdsmen, communal clashes, indigenous peoples of Biafra's agitation etc. Against this backdrop, Yagboyaju and Akinola (2019:8) posit that "the Nigerian government has failed to guarantee the security of a large section of the population, and militancy and insurrection have militated against effective governance since the return of civil rule in 1999". Therefore, Nigeria typifies a perfect example of a failed state. According to Rotberg, 2003 cited in Oko et al., (2018:36), a failed state is a state that "can no longer deliver positive political goods to their people such as security, healthcare, social infrastructure, employment opportunities and the legal framework for law and order". Similarly, Eke (2013:96) posits that "the continual downward trend in unemployment, poverty, corruption, epileptic power supply, increased general insecurity and crime in the country are core indices of a weak and failed state. This is further demonstrated by executive ineptitude and heightened tension of terrorism, communal conflicts, politicalreligious conflict and capital flight with deepened economic depression and debt burden". It is pertinent to stress that security must be patterned in a way that the individual is the primary focus for any security formation. That is, security must be people driven or oriented to assure citizens that government is competent, capable and efficiently ready to guarantee their safety and freedom of movement that enables them to carry out their socio-economic activities without intimidation, violent threat or harassment from any person or group of persons within the polity. 


\subsection{Human Security: The Panacea to Security Challenges in Nigeria}

During the Cold War epoch, the concept of security has been traditionally perceived or associated with the whole gamut of processes defined in terms of the capacity of the coercive apparatus of the state to uphold sovereignty, defend territorial integrity, ensure stability and peace as well as pursue armed conflict. Nevertheless, the end of the cold war in 1990s marked a paradigm and fundamental departure from the state-centered (Military capability) of state approach, ideologically rooted in the theoretical orientations of political realism to human security usually defined as 'peoples or individual-centered'. Evidently, "the need to jettison the traditional conception of security and embrace the people-centered approach owes largely to the admixture and convergence of various factors including the failure of liberal state building through the instruments of the Washington Consensus, increasing number of internal violent conflicts in Africa, Asia and east-Europe, the increasingly rapid pace of globalization, the exponential rise in the propagation and consolidation of democracy and the incapacity of the neoliberal development models to catalyze economic growth in the developing countries or systematically deal with the effects of complex emerging threats such as HIV, terrorism and climate change" (Okolie \& Nnamani, 2017:93-94).

Accordingly, United Nations, 2004 cited in Okolie and Nnamani (2017:94) affirm that "the only feasible way of securing the international system against threats was through the merging of development and security. That is, prioritizing the emancipation and development of the individual at 6 the centre of the security agenda, otherwise known as human security. Thus, human security is a new and broadened approach in security studies which seeks to explicate the global vulnerabilities and examine how poverty, environment and social interaction generate conflict and increasingly poses threat to human existentialism". Central to this approach is the understanding that human security deprivations can undermine peace and stability within and between states, whereas an overemphasis on state-centered security can be detrimental to human welfare (United Nations, 1994). Human security is not an attack on state or national security, but a complementary view to state security. This is because without the security of humans, national and regional security will be difficult to achieve. Human security holds that a people-centered view of security is necessary for regional, national and global stability.

Human security refers to "the degree to which the welfare of individuals is protected and advanced. It also entails empowering people and societies" (Ndubuisi, 2017:58). The UNDP (1994:23) sees human security as "safety from such chronic threats as hunger, disease, and repression,, and protection from sudden and hurtful disruptions in the patterns of daily life". It further argues that the scope of human security should be broadened to include threats in seven areas: economic security, political security, community security, food security, health security, personal security and environmental security. Thus, the insecurities that threatened human survival or the safety of daily life or imperil the natural dignity of man, or expose human beings to the uncertainty of disease and pestilence, or subjected vulnerable to abrupt penury related to economic, downturns demand that special attention be paid to the dangers of sudden deprivation. Human security demands protection from these dangers and the empowerment of people to cope with-and when possible overcome the hazards (Commission on Human Security, 2003 cited in Ndubuisi, 2017).

The UNTFHS, 2009 cited in Onifade et al., (2013) argues that a distinctive component of human's ecurity is its focus on early prevention to minimize the impacts of insecurity, to engender long-term solutions and to build human capacities for undertaking preventions. Human security should form the fulcrum on which national security and integration must be built and sustained as it is the only assurance that democratic dividends will cut across all sectors of the human strata. Therefore, human beings should constitute the referent in the definition of security in the ngieria context. It is Nigerians thata re imperiled and not the state, because there is no country threatening the existence of Nigeria (Onoja,2014). If the seven dimensions of human security (economic security, political security, food security, community security, health security, personal security and environmental secutiry) is carefully applied in Nigeria, the threats of insecurity will no longer have its grip on the national security. This is because human security aims to address complex situait6ons of insecurity through collaborative, responsive and sustainable measures that are (i) people-centered (ii) multi-sectoral (iii) comprehensive and (iv) prevention-oriented (UNTFHS, 2009 cited in Ndubuisi, 2017). Therefore, Nigerian government must intensify efforts to address poverty, unemployment that generates tensions, fear and insecurity across the country.

\subsection{Theoretical Framework}

While there are several theories which might prove appropriate for a discourse of this nature, the natural state theory present us with a heuristic too for interrogating the central issue of the study. Absed upon the work of Jowett (1885) and Coplestone (1946), the natural state theory rests on the assumption that the state emerged in order to provide the needs of every individual within the polity, given that human beings cannot satisfactorily provide their basic need. According to Aristotle cited in Zarri (1948:1), "the state must exist for an end, and the end upon which the state exists is the highest good of man", that is having a platform that will ensure the satisfaction of the basic needs individual cannot provide for himself/herself. This highest good of man was 
captured as pursuit of happiness by Aristotle. He described happiness as central to human existence and a necessary goal to be pursued. The highest good of man is also described as "a life of virtue and contemplation" (Zarri, 1948;1). Aristotle equated the state of community and portends that all communities aim at some good in a greater degree than any other body. Nnoli (2003) while trying to define the concept of state noted that Aristotle defined state as a kind of community. Nnoli (2003: 26) argues that "a community is a union of unlike persons who are able to satisfy their needs by their exchange of goods and services. To achieve the basic needs of life, Sabine and Thorson, 1973 cited in Ndubuisi (2017:56) noted that "man must understand the potentialities of growth that are available and the possible means for actualizing the required basic needs of man". In the view of Zarri (1948:1), "there are two basic instincts or needs which are fundamental in bringing people together. These are: (i) the reproductive instinct 9ii) the self-preservation".

The reproductive instinct was seen as what led to conjugal relationship between female and male. The relationship between woman and gave rise to the family. The family being an association which was established by nature performs the role of supplying everyday needs of man. The family is the first and smallest unit in the formation of the state and it grew into villages by the conglomeration of families, from villages emerged a single complete community, which is large enough to cater for the basic needs of life and the state metamorphosed from the community. That is, the state originated from the basic needs of life and continues to exist for the sake of a good life (Zarri, 1948; Nnoli, 2003; Ndubuisi, 2017, Peterside, 2018; Yagboyaju \& Akinola, 2019). From the foregoing, it is important to emphasize that the provision of human basic needs of life is the primary goal of the state and it is the surest measure to ensuring peace, stability and tranquility. In applying the basic assumptions of the natural state theory to the present study, we note that the state is an objective force that holds the society together. The role of the state are many and varied, but the main responsibilities of the state are provision of basic needs of every citizen and the maintenance of social and political order in the polity.

\section{Conclusion and recommendations}

The Nigerian government inability to address the human needs, particularly among the teeming youths is the root cause of security challenges. The growing dissatisfaction, distress and discomfort within the polity coupled with poverty and high rate of unemployment, unabating official corruption, economic crisis, lack of essential basic amenities and a futile national integration project have heated up the socio-political environment. The youths are aggrieved and therefore resort to aggression against the society. Consequently, political motivated assassination, kidnappings, insurgence and terrorism, ethno-religious conflicts, communal clashes, herdsmen's banditry, militancy, armed robberies, abductions and other forms of violence crimes have created survival, stability and security challenges in the country. This study concludes therefore that fortifying the security walls with latest security equipment and gadgets as well as assigning security experts or professionals to secure the Nigerian state will amount to nothing if the threats of hunger, disease, unemployment, abject poverty, lack of basic social amenities, economic and political exclusion and corruption are not addressed. Security centric perspective that focuses on improving the existential conditions of citizens as well as ensuring the corporate existence of the state. In order to provide long lasting solution to the disturbing trend of security challenges in Nigeria, the following recommendations are made:

1)Federal government should intensity efforts to ensure employment generation and genuine implementation of poverty alleviation programmes. While the states or regional government should investment more on war against hunger, disease and lack of basic social amenities.

2)The Nigerian government should strengthen the security apparatus to responds to security threats against the citizens across the country through capacity building.

3)A sustainable means of livelihood should be created by Nigerian state for the younger generation so as to avoid being easily sway into becoming raw materials for seen threats to human security.

4)Government should sincerely tackle the issue of corruption in the polity in order to demonstrate their willingness to alleviate challenges associated with abject poverty, acute youth unemployment and infrastructural dilapidation across the country.

\section{References}

Baki, A. (2008). Kuramdan uygulamaya matematik ĕgitimi. Ankara: Harf Eğitim Yayıncılı̆̆ı

Peterside, Z.B. (2018). The Imapcts of Proliferation of Small Arms and Light Weapons on the Quest for National Security in Nigeria. Saudi Journal of Humanities and Social Sciences, 3(7), $852-860$.

Eke. C.C. (2013). The Challenges of Conflict Management in a Democratic Soceity: An Overview of Insecurity in Nigeria. American International Journal of Social Science, 2(3), 93 - 107.

Onifade, C., Imhonopi, D., Urim, U.M. (2013). Addressing the Insecurity Challenge in Nigeria: The Imperative of Moral Values and Virtue ethics. Global Journal of Human-Social Science, 13(2), 53 - 63.

Oko, E., Ufomba, H., \& Benjamin, W. (2018). Is Nigeria a Failed State? A Commentary on the Boko Haram Insurgency. Global Journal of Human-Social science, 18(5), 35 - 38. 
Yagboyaju, D.A., \& Akinola, A.O. (2019). Nigerian State and the Crisis of Government: A Critical exposition. Sage Open, July - September, $1-10$.

Onoja, A.F. (2014). In Search of the Causes of Insecurity in Nigeria: A Note on Administrations and their Agenda. Journal of Conflictology, 5(1), $33-42$.

Ndubuisi, I.S. (2017). Human Security: Dealing with the Threats to Human Existence in Nigeria. Studies in Politics and Society, 5(1), $53-73$.

Okolie, A., \& Nnamani, K.E. (2017). Fulani Herdsmen Militancy, Environmental Security and Sustainability of Livelihood in Nigeria. Studies in Politics and Society, 5(1), $93-112$.

Omemma, D.A. (2017. Security Challenges and democratic Consolidation in Nigeria: An Exploration. Studies in Politics and Society, 5(1), $126-140$.

Babangida, I.B. (2002). Ethnic Nationalities and the Nigerian State: The Dynamics and Challenges of Governance in a Plural Nigeria. Distinguished Annual Lecture at National Institute for Policy and Strategic Studies, Kuru, Nigeria.

Kwaja, C. (2009). Strategies for rebuilding State capacity to Manage ethnic and Religious Conflict in Nigeria. Journal of Pan African Studies, 3, $105-115$.

Yagboyaju, D.A. (2016). Peace and Security. In D.A. Yagboyaju (Ed.). Reflection on Politics, Governance and the economy in Contemporary Nigeria. Ibadan: Ibadan University Press, Pp.35 - 68 .

United Nations Development Programme. (1994). Human Security and development report, 1994 /1995: Fighting Against Insecurity. New York: Author Publishers.

Beland, D. (2005). The Political Constitution of Collective Insecurity: From Moral Panic to Blame Avoidance and Organized Irresponsibility. Europe: Centre for European Studies Working Paper Series 126.

UNDP. (2002). World Bank and WRI. World Resources, 87 - 102.

Omonobi, K. (2016). Recruitment of 10,000 Men into Police. Vanguard Newspaper, March 24.

Adagbabiri, M.M. \& Okolie, U.C. (2018). Corruption and the Challenges of Insecurity in Nigeria's Fourth Republic. Journal of Political Science and Leadership research, 4(3), $41-56$.

Ewetan, O.O. \& Urhie, e. (2014). Insecurity and Socio-economic Development in Nigeria. Journal of Sustainable development Studies, 5(1), $40-63$.

Nnoli, O. (2003). National Security in Africa: A Radical New Perspective. Enugu: PACREP Publishers.

Eugina, O. (2013). Hpow to stop Terrorism in nigeria. JSOU Report, 3(4), 108 - 117.

Ujomu, E. (2001). Security Challenges and Nigerian State Economy. International Society, 8(2), $143-156$.

Jowette E. (1885). Duty of State. New York: McGraw-Hill.

Coplestone, C. (1946). State and Human Well-Being. Moslow: Progress Publishers.

Zarri, A.J. (1948). State Theory. London: Penguin. 